\title{
Does molybdenum and cobalt foliar spray mitigate nitrate starvation and ammonium deprivation stress?
}

\author{
Rodrigo Antonio Nuncio Junior ${ }^{1}$, Daniel Baron², Iuri Emmanuel de Paula Ferreira ${ }^{3}$
}

\begin{abstract}
Knowledge about the nutritional balance at the initial phenological stage is mandatory to overcome limitations on nutritional availabilities required by the plant species. However, little is elucidated about nitrate $\left(\mathrm{NO}_{3}^{-}\right)$and ammonium $\left(\mathrm{NH}_{4}^{+}\right)$deprivation stress. Our hypothesis tested is that there are benefits of the foliar application (spray) of molybdenum (Mo) and cobalt (Co) under different availabilities (ionic strength, IS) from the presence of nitric sources $\left(\mathrm{CaNO}_{3}^{2-}\right)$ and absence of ammonium $\left(\mathrm{NH}_{4} \mathrm{H}_{2} \mathrm{PO}_{4}\right)$ in root application (hydroponic cultivation) at the initial phenological growth stage. Nutrient supply was carried out with a nutrient solution, which is deprived of $\mathrm{NH}_{4}^{+}$. Treatments were $25 \%, 50 \%$, and $100 \%$ IS, supplied via hydroponic cultivation, combined with the absence/presence of $\mathrm{Co} / \mathrm{Mo}$ spray. Plants were randomly distributed into 17 blocks (replicates) with 6 treatments conducted in a factorial scheme and data were analyzed by ANOVA and ANCOVA. We observed that $\mathrm{Co} / \mathrm{Mo}$ spray diminished plant growth discrepancies between treatments at different IS's. In addition, contents of photosynthetic pigments were higher at $25 \%$ IS without Co/Mo spray. Thus, we concluded that Mo and Co spray can alleviate $\mathrm{NO}_{3}^{-}$starvation/ $\mathrm{NH}_{4}^{+}$deprivation stress during the initial growth phenological stages of yellow passion fruits.
\end{abstract}

Index terms: abiotic stress; beneficial mineral elements; essential mineral elements; hydroponic; passiflora; plant nutrition.

\section{Aplicação foliar de cobalto e molibdênio mitiga a privação de nitrato e ausência de amônio?}

Corresponding author: danielbaron@ufscar.br

Received:December 15, 2020 Accepted: April 12, 2021

Copyright: All the contents of this journal, except where otherwise noted, is licensed under a Creative Commons Attribution License.

(cc) $\mathbf{E Y}$
Resumo - O conhecimento do balanço nutricional na fase fenológica inicial é crucial para contornar as limitações das disponibilidades nutricionais exigidas por espécies vegetais. No entanto, pouco é sabido sobre o estresse de privação de nitrato $\left(\mathrm{NO}_{3}^{-}\right)$e ausência de amônio $\left(\mathrm{NH}_{4}^{+}\right)$. Nossa hipótese testou se há benefícios da aplicação foliar (spray) de molibdênio (Mo) e cobalto (Co) em diferentes disponibilidades (força iônica, IS), a partir da presença restrita de $\mathrm{N}$ em fontes nítricas $\left(\mathrm{CaNO}_{3}{ }^{2-}\right)$ e ausência de $\mathrm{N}$ em formas amoniacais $\left(\mathrm{NH}_{4} \mathrm{H}_{2} \mathrm{PO}_{4}\right.$ ), por aplicação radicular (cultivo hidropônico), na fase fenológica de crescimento inicial. Nutrientes foram fornecidos usando solução nutritiva, desprovida de $\mathrm{NH}_{4}^{+}$. Os tratamentos empregados foram $25 \%, 50 \%$ e $100 \%$ IS, fornecidos via cultivo hidropônico, combinados com ausência / presença de pulverização de Co/Mo. As plantas foram distribuídas ao acaso, em 17 blocos (repetições), com 6 tratamentos conduzidos em esquema fatorial, e os dados foram analisados por ANOVA e ANCOVA. Observou-se que a pulverização de Co/Mo diminuiu as discrepâncias entre o crescimento da planta em diferentes ISs. Além disso, os conteúdos de pigmentos fotossintéticos foram maiores que $25 \%$ IS sem pulverização de Co/Mo. Assim, concluiu-se que a pulverização foliar de Mo e Co pode aliviar o estresse de privação de $\mathrm{NO}_{3}^{-}$/ausência de $\mathrm{NH}_{4}^{+}$durante os estágios fenológicos de crescimento inicial do maracujá-amarelo.

Termos para indexação: estresse abiótico; elementos minerais benéficos; elementos minerais essenciais; hidroponia; passiflora; nutrição vegetal. 


\section{Introduction}

Fresh yellow passion fruits [Passiflora edulis Sims. f. flavicarpa Degener] and derivatives are sources of antioxidants beneficial to human health, which makes this species an economic alternative for small farmers (OLUOCH; NYABOGA; BARGUL, 2018). Commercial orchards with high productivity and economic profitability comes from the use of seedlings with excellent vigor and nutritionally balanced. It is crucial to plants adapted to the constant environmental changes, for example, nitrogen $(\mathrm{N})$ forms of starvation and/or deprivation in the soil (WANG; MIAO; LI, 2015).

Ammonium $\left(\mathrm{NH}_{4}^{+}\right)$and nitrate $\left(\mathrm{NO}_{3}^{-}\right)$are major nitrogen $(\mathrm{N})$ forms taken up by plants, and amounts consist of $50 \%$ above total ions (YIN; LUO; WANG; SHEN et al., 2014). Plants have different $\mathrm{NH}_{4}^{+}$uptake preferences, but to seedlings, it is poorly understood. At initial phenological growth stages, literature reported that these two forms were both effective $\mathrm{N}$ sources for the direct absorption of plants and several hydroponic experiments have investigated of $\mathrm{NH}_{4}^{+}$and $\mathrm{NO}_{3}{ }^{-}$uptake (HUANG; LI; ZHOU; SUN et al., 2018).

According to Zeng and colleagues (ZENG; XU; WU; HUANG et al., 2014) plants grown in nutrient solution with lower $\mathrm{N}$ availability have lower total chlorophyll concentrations, since this nutrient is an integral part of photosynthetic pigments, Ribulose 1,5-Bisphosphate Carboxylase/Oxygenase (RuBisCO) (ESTRADA; BÖHLKE; STURCHIO; GU et al., 2017) however, there is no single nutrient solution common to all plant species and/or phonological stages.

Molybdenum (Mo) is beneficial for leaf application in young strawberry plants (Fragaria $x$ ananassa Duch. cv. Akihime), since it improves $\mathrm{NO}_{3}^{-}$transport by roots and increasing the efficient use of $\mathrm{N}$ by plants (LIU; BURGOS; ZHANG; TANG et al., 2017). This essential mineral promotes the enzymatic catalysis of a series of biochemical reactions, for example, synthesis of phytohormones, sulfite detoxification (HIPPLER; BOARETTO; DOVIS; GOMES et al., 2017). The transport of nitrogen compounds essential in eukaryotic organisms, such as molybdoenzymes, bind to Pterine $\left(\mathrm{C}_{6} \mathrm{H}_{5} \mathrm{~N}_{5} \mathrm{O}\right)$ to form the MoCo cofactor, and a constituent of the nitrate reductase enzyme (CHATTERJEE; BANDYOPADHYAY, 2017; HÄNSCH; MENDEL, 2009). In this way, the higher the nitrate reductase activity, the lower the nitrate content in the cytoplasm of plant cells.

Cobalt $(\mathrm{Co})$ is considered a beneficial mineral element for plants, used as cofactor of various enzymes and proteins; however, scientific reports have pointed to irreversible damage in barley genotypes (Hordeum vulgare L.), such as reduction in cell division, vein discoloration, leaf abscission, abnormal translocation of root-to-leaf nutrients and chloroplast integrity and iron-porphyrin enzyme disorders (LANGE; FAUCON; DELHAYE; HAMITI et al., 2017; SHAHID; DUMAT; KHALID; SCHRECK et al., 2017). This heavy metal, compared to other metals, has been less explored in plant physiology (or physiological) studies. In addition, Co also influences $\mathrm{N}$ (symbiotic) absorption by being a structural part of leghemoglobin synthesis, which determines the activity of nodules in roots (WILSON; NICHOLAS, 1967).

In this way, our hypothesis is that there are benefits of the foliar application (spray) of Mo and Co under different availabilities (ionic strength, IS) from a single $\mathrm{N}$ (nitric presence $\mathrm{CaNO}_{3}{ }^{2-} /$ ammonium absence $\mathrm{NH}_{4} \mathrm{H}_{2} \mathrm{PO}_{4}$ ) source of root application (hydroponic cultivation) on nutritional balance during the formation of seedling at initial phenological stage. The aims were to reveal if early growth phenological stages respond to $\mathrm{Co} / \mathrm{Mo}$ spray under the condition of $\mathrm{NO}_{3}^{-}$starvation and $\mathrm{NH}_{4}^{+}$deprivation and to evaluate the leaf application of mineral elements molybdenum (Mo) and cobalt ( $\mathrm{Co}$ ) in yellow passion fruit cultivated under different availabilities (ionic strength, IS) of Hoagland and Arnon No.01 nutrient solution mineral.

\section{Material and methods}

\section{Plant material and experimental procedure}

The present study was conducted in an experimental area belonging to the Federal University of São Carlos (UFSCar) Lagoa do Sino campus, municipality of Buri/ SP, at height of 596 meters above sea level and with the following geographical coordinates: Latitude (23 $47^{\prime} 57^{\prime \prime}$ $\mathrm{S})$, and Longitude (48 $\left.35^{\prime} 15^{\prime \prime}\right)$. Ripe yellow passion fruits (Passiflora edulis Sims f. flavicarpa Degener) were collected from a single-mother plant, manually pulped with the aid of a sieve and running water and, after washing, seeds were kept in a drying bench. Seeds were submitted the phytosanitary treatment carried out in polystyrene trays filled a medium texture vermiculite substrate. Seedlings were transplanted to pots as soon as they presented the first pair of fully expanded leaves.

\section{Treatments}

Young plants were transplanted to plastic tubes with $0.3 \mathrm{~L}$ volumetric capacity and filled with medium texture vermiculite substrate. Previously, the Hoagland and Arnon No. 01 nutrient solution was improved (HOAGLAND; ARNON, 1950), being composed of unique nitrogen (nitrate) source $\left(\mathrm{CaNO}_{3}{ }^{2-}\right)$ and absence of ammonium $\left(\mathrm{NH}_{4}^{+}\right)$and used in the hydroponic technique with small methodological adjustment, according to Campos and collaborators (CAMPOS; VIEIRA; AMARO; DELACRUZ-CHACÓN et al., 2019). The different Hoagland's electrical conductivities (EC) employed were $25 \%\left(0.25 \mathrm{dSm}^{-1}\right), 50 \%\left(1.00 \mathrm{dSm}^{-1}\right)$ and $100 \%\left(2.00 \mathrm{dSm}^{-1}\right)$ ionic strength (IS) (Table 1). Co and 
Mo foliar application (Co/Mo spray) was prepared with cobalt(II) sulfate heptahydrate $\left(\mathrm{CoSO}_{4} \cdot 7 \mathrm{H}_{2} \mathrm{O}\right.$, molecular weight $281.10 \mathrm{~g} . \mathrm{mol}^{-1}$ ) and sodium molybdate dihydrate $\left(\mathrm{Na}_{2} \mathrm{MoO}_{4} \cdot 2 \mathrm{H}_{2} \mathrm{O}\right.$, molecular weight $\left.205.92 \mathrm{~g} \cdot \mathrm{mol}^{-1}\right)$ in aqueous ion solutions of $0.3 \mathrm{~mL} . \mathrm{L}^{-1}(300 \mathrm{ppm})$ and 4.0 $\mathrm{mL} . \mathrm{L}^{-1}(4000 \mathrm{ppm})$, respectively. Aqueous ion solutions were applied in young plants with the aid of costal sprayer with $\mathrm{CO}_{2}$ cylinder and pressure gauge measurement through a single fan tip (MagnoJet ${ }^{\mathbb{B}}$, model AD/T 110 $02)$, according to manufacturer's recommendations. The description of treatments is the following: $\mathrm{T} 1=25 \% \mathrm{IS}$ without $\mathrm{Co} / \mathrm{Mo}$ spray; $\mathrm{T} 2=50 \% \mathrm{IS}$ without $\mathrm{Co} / \mathrm{Mo}$ spray; $\mathrm{T} 3=100 \%$ IS without Co/Mo spray; $\mathrm{T} 4=25 \% \mathrm{IS}$ plus $\mathrm{Co} /$ Mo spray; $\mathrm{T} 5=50 \% \mathrm{IS}$ plus Co/Mo spray; $\mathrm{T} 6=100 \% \mathrm{IS}$ plus $\mathrm{Co} / \mathrm{Mo}$ spray.

\section{Plant growth and growth analysis}

Plant height, plant length, stem diameter, and leaf area were measured in 17 replicates, at 8 collection times $(15,30,45,60,75,90,105$, and 120 days after transplantation - DAT). In addition, 3 replicates (plants) from each treatment were used at 120 DAT to separate into shoots and roots. Subsequently, leaf, stem, and roots were dried in a forced convection benchtop oven $(65 \pm$ $2^{\circ} \mathrm{C}$ ), for $72 \mathrm{~h}$ until constant dry matter measured with the aid of analytical scale with $0.001 \mathrm{~g}$ sensitivity to obtain leaf dry matter (LDM), stem dry matter (SDM) and root dry matter (RDM) (BENINCASA, 1986).

Table 1. Hoagland and Arnon's nutrient solution $\mathrm{n}^{\circ} 1$ (absence ammonium source, $\mathrm{NH}_{4}^{+}$) containing macronutrients, with different nitrogen concentrations, micronutrients, and iron-EDTA solution.

\begin{tabular}{|c|c|c|c|c|}
\hline Macronutrients & Stock solution $(\mathrm{M})$ & $\begin{array}{l}25 \% \mathrm{~N} \\
\left(\mathrm{~mL} \cdot \mathrm{L}^{-1}\right)\end{array}$ & $\begin{array}{l}50 \% \mathrm{~N} \\
\left(\mathrm{~mL} \cdot \mathrm{L}^{-1}\right)\end{array}$ & $\begin{array}{l}100 \% \mathrm{~N} \\
\left(\mathrm{~mL} \cdot \mathrm{L}^{-1}\right)\end{array}$ \\
\hline $\mathrm{KH}_{2} \mathrm{PO}_{4}$ & 136.08 & 1.00 & 1.00 & 1.00 \\
\hline $\mathrm{KNO}_{3}$ & 101.10 & 1.25 & 2.50 & 5.00 \\
\hline $\mathrm{Ca}\left(\mathrm{NO}_{3}\right)_{2}$ & 236.16 & 1.25 & 2.50 & 5.00 \\
\hline $\mathrm{Mg}\left(\mathrm{SO}_{4}\right) \cdot 7 \mathrm{H}_{2} \mathrm{O}$ & 246.50 & 2.00 & 2.00 & 2.00 \\
\hline$(0.5 \mathrm{M}) \mathrm{K}_{2} \mathrm{SO}_{4}$ & 087.13 & 3.77 & 2.50 & 0.00 \\
\hline$(0.01 \mathrm{M}) \mathrm{CaSO}_{4}$ & 001.36 & 300.00 & 200.00 & 000.00 \\
\hline Micronutrients & Stock solution $\left(\mathrm{g} . \mathrm{L}^{-1}\right)$ & 1.0 & 1.0 & 1.0 \\
\hline $\mathrm{H}_{3} \mathrm{BO}_{3}$ & 2.86 & & & \\
\hline $\mathrm{MnCl}_{2} \cdot 4 \mathrm{H}_{2} \mathrm{O}$ & 1.81 & & & \\
\hline $\mathrm{ZnSO}_{4} \cdot 7 \mathrm{H}_{2} \mathrm{O}$ & 0.22 & & & \\
\hline $\mathrm{CuSO}_{4} \cdot 5 \mathrm{H}_{2} \mathrm{O}$ & 0.08 & & & \\
\hline $\mathrm{H}_{2} \mathrm{MoO}_{4} \cdot \mathrm{H}_{2} \mathrm{O}$ & 0.02 & & & \\
\hline Iron-EDTA Solution* & Stock solution $\left(\right.$ g. $\left.\mathrm{L}^{-1}\right)$ & 1.0 & 1.0 & 1.0 \\
\hline Bissodic EDTA $\left(\mathrm{C}_{10} \mathrm{H}_{14} \mathrm{~N}_{2} \mathrm{O}_{8} \mathrm{Na}_{2} \cdot 2 \mathrm{H}_{2} \mathrm{O}\right)$ & 26.10 & & & \\
\hline $\mathrm{FeSO}_{4} \cdot 7 \mathrm{H}_{2} \mathrm{O}$ & 24.90 & & & \\
\hline
\end{tabular}

*Solution catalyzed by $265.00 \mathrm{~mL} \mathrm{NaOH}(\mathrm{M})$.

\section{Photosynthetic pigments}

The contents of chlorophylls $(a$ and $b$ ) and carotenoids were measured on 6 replicates per treatment according to methodology of Sims and Gamon (SIMS; GAMON, 2002). The concentration ( $\mu \mathrm{g}$ of pigment per $\mathrm{g}$ of fresh matter) of chlorophylls $a$ and $b$ and carotenoids were calculated according to the following equations:

I. Chlorophyll $a=0.01373$. (A663) - 0.000897 . (A537) - 0.003046. (A647);

II. Chlorophyll $b=0.02405$. (A647) - 0.004305 . (A537) 0.005507. (A663);

III. Carotenoid $=[\mathrm{A} 470-(17.1 .(\mathrm{Cl} a-\mathrm{Cl} b)-9.479$. (Anthocyanin)] / 119.26.

\section{Statistical methods}

Plants were randomly distributed into 17 blocks (replicates) with 6 treatments. Treatments were composed of a factorial scheme with 3 ionic strengths $(25,50$, and $100 \%$ ) combined with 2 levels of Co/Mo foliar spray (present/absent). Firstly, the data were analyzed through descriptive statistics using profile charts, histograms, and mean plots (with mean standard errors). Regarding plant growth measurements, the analysis of variance (ANOVA) was performed within each collection time. On the other hand, data from destructive sampling (at 120 DAT) were evaluated by of covariance analysis (ANCOVA). Initial height and length (at 15 DAT) were used as covariates in the growth analysis and pigment contents, while diameter and initial stem length were used as covariates to dry 
matter data. The ANOVA and ANCOVA validity was verified through residual charts and normality and variance homogeneity tests (Shapiro-Wilk's and Brown-Forsythe's, respectively). Logarithmic transformation was necessary to normalize and homogenize data variance in the case of pigment contents. Correlations between pigments were studied by Pearson's linear correlation coefficient and tested using student's $t$ distribution. The Scott-Knott test was used to describe the pattern of influence of treatments on growth responses. In the case of significant effects on ANCOVA, adjusted means were compared by Tukey's test. All statistical analyses were conducted with $R$ software and significance tests were performed by setting $\alpha=0.05$.

\section{Results and discussion}

\section{Plant growth and growth analysis}

Plant height and length measures were affected by $\mathrm{NO}_{3}^{-}$availability (i.e., ionic strength, IS) and $\mathrm{Co}$ and Mo foliar application (Co/Mo spray) at the majority of plant collection times (Table 2, $\mathrm{P}<0.05$ ). However, there was no significant interaction between IS and spray application ( $\mathrm{P}>0.05)$, with the exceptions of 60 DAT for plant height and 60 and 75 DAT for plant height and plant length. The effects of experimental factors on stem diameter seem to be occasional, and no consistent response pattern was observed over time (Table 2). Concerning leaf area, there was an effect of $\mathrm{NO}_{3}{ }^{-}$availabilities at almost all collection times (Table 2, $\mathrm{P}<0.05$ ). However, no effect of foliar spray application and significant interactions between IS and spray were observed $(\mathrm{P}>0.05)$. The Scott-Knott test was used to group treatments with the same response pattern at each collection time (Figure 1). Considering plant height and length, treatment T6 (100\%IS plus Co/Mo spray) provided the highest values at all collecting times, with the other treatments being combined in a group marked for lower results $(\mathrm{P}<0.05)$. In relation to stem diameter, all treatments were grouped until 90 DAT; but after that, treatment T6 presented the highest values $(\mathrm{P}<0.05)$, and the other treatments provided lower results. Considering leaf area, T6 showed better results from 75 DAT in comparison to the other treatments $(\mathrm{P}<0.05)$; however, T3 (100\%IS without Co/Mo spray) showed intermediate plant growth, being grouped together with T6 from 90 DAT. Thus, plant growth responds to $\mathrm{NO}_{3}{ }^{-}$increases, even in the absence of $\mathrm{NH}_{4}^{+}$, and the $\mathrm{Co} / \mathrm{Mo}$ spray provided additional growth, ensuring better plant establishment and mitigating the effects of $\mathrm{NH}_{4}^{+}$deprivation. Except for SDM, no significant effects on growth analysis were found (ANCOVA, P $>0.05$ ). Significant interaction between $\mathrm{Co} /$ Mo spray and IS's was observed (ANCOVA; $F=7.702$, degree-of-freedom $=2 / 10, \mathrm{P}=0.009)$. In low EC (25\% IS), $\mathrm{SDM}$ showed similar results regardless of $\mathrm{Co} / \mathrm{Mo}$ spray (Figure 2). However, SDM showed higher value under
Co/Mo spray when compared with control at 'moderate' EC (50\%IS), although the mean difference was not statistically significant $(\mathrm{P}>0.05)$. In high EC (100\%IS), the pattern was inversed, and mean SDM value under foliar Mo and Co applications was lower than that of control (Figure 2; $\mathrm{P}<0.05$ ).

\section{Photosynthetic pigments}

Photosynthetic pigments (cla, $\mathrm{cl} b$, and car) were linear and positively correlated (Figure 3; $\mathrm{P}<0.05$ ). Also, pigment data were asymmetrically distributed and, therefore, Box and Cox's transformations were used before inferential analyses. In low EC (25\% IS), pigment content was considerably higher in the absence of $\mathrm{Co} / \mathrm{Mo}$ spray (Figure 4) and significant interactions between $\mathrm{EC}$ and $\mathrm{Co} /$ Mo spray were observed $(\mathrm{P}<0.05$; Table 3$)$. In addition, significant main effect of $\mathrm{Co} / \mathrm{Mo}$ spray on cla and car was also observed, although no significant effects of EC on pigment content was observed. Plants treated with Co/Mo spray show mean cla contents statistically equal at $25 \% \mathrm{IS}, 50 \% \mathrm{IS}$, and $100 \% \mathrm{IS}$ (Figure 4). Meanwhile, for $\mathrm{cl} b$ and car, no differences between 50\%IS and $100 \%$ IS were found; however, $\mathrm{cl} b$ and car contents were statistically smaller at $25 \%$ IS when compared to $100 \%$ IS $(\mathrm{P}<0.05)$. This physiological pattern is the opposite when compared to ISs in the absence of Co/Mo spray, because pigment contents were higher at low EC (25\% IS), while mean pigment contents were equal at $50 \%$ IS and $100 \%$ IS (Figure 4).

Our study verified the benefits of $\mathrm{Co} / \mathrm{Mo}$ spray in the initial phenological growth stage of yellow passion fruits cultivated in Hoagland and Arnon nutrient No.1 solution $\left(\mathrm{NH}_{4}^{+}\right.$deprivation). Nitrogen $(\mathrm{N})$ plays an important role in plant growth and mediation of root and shoot development, which main forms are $\mathrm{NO}_{3}^{-}$and $\mathrm{NH}_{4}^{+}$, and between these two forms, $\mathrm{NO}_{3}{ }^{-}$is the most absorbed, as it is the most available mineral $\mathrm{N}$ form in the soil or nutrient solution (HAWKESFORD; HORST; KICHEY; LAMBERS et al., 2012). However, it remains unclear if crops can change their preference during their early phenological growth stages. The present study indicates that plant growth responses are severely affected by the absence of the $\mathrm{NH}_{4}^{+}$source. $\mathrm{NO}_{3}{ }^{-}$requires higher metabolic energy (use of ATP) for its assimilation in organic matter when comparing to $\mathrm{NH}_{4}^{+}$. Since $\mathrm{NO}_{3}^{-}$is absorbed in the oxidized form, and subsequently reduced to ammonia $\left(\mathrm{NH}_{3}\right)$ to be incorporated in the form of amino acids (glutamate). Unlike $\mathrm{NH}_{4}^{+}, \mathrm{NO}_{3}^{-}$is readily absorbed for later incorporation and, consequently, $\mathrm{NH}_{4}^{+}$demands lower metabolic expenditure. Usually, plants prefer $\mathrm{NH}_{4}^{+}$ as the major nitrogen $(\mathrm{N})$ source, because the uptake of ${ }^{15} \mathrm{~N}$ from ${ }^{15} \mathrm{NH}_{4}^{+}$is more quick than that from ${ }^{15} \mathrm{NO}_{3}^{-}$, as there is a more efficient expression pattern of $\mathrm{NH}_{4}^{+}$protein carrier compared with $\mathrm{NO}_{3}{ }^{-}$. In plants, $\mathrm{NH}_{4}^{+}$accumulated more than $\mathrm{NO}_{3}{ }^{-}$(TANG; LIU; ZHANG; MA et al., 2020). 


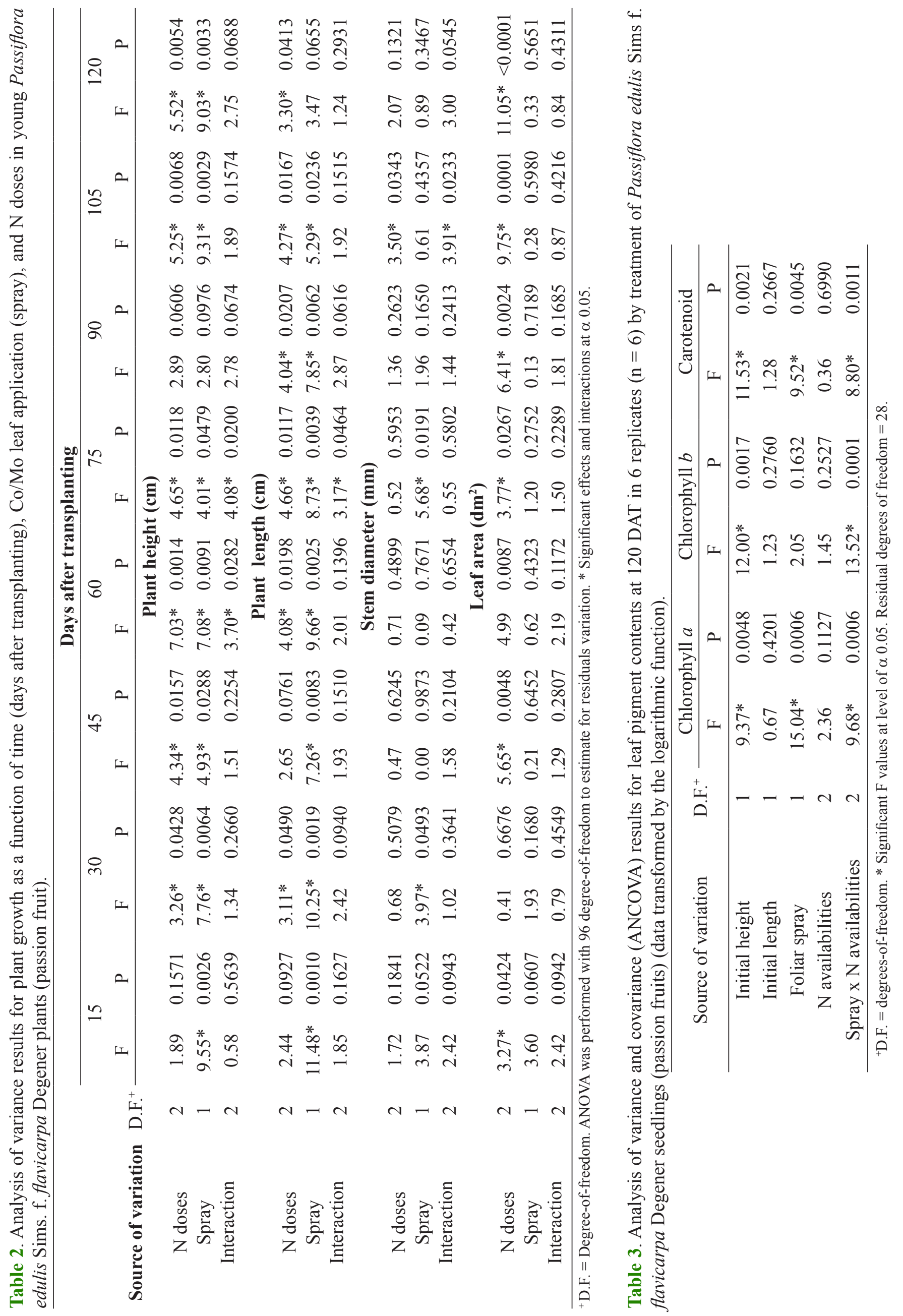



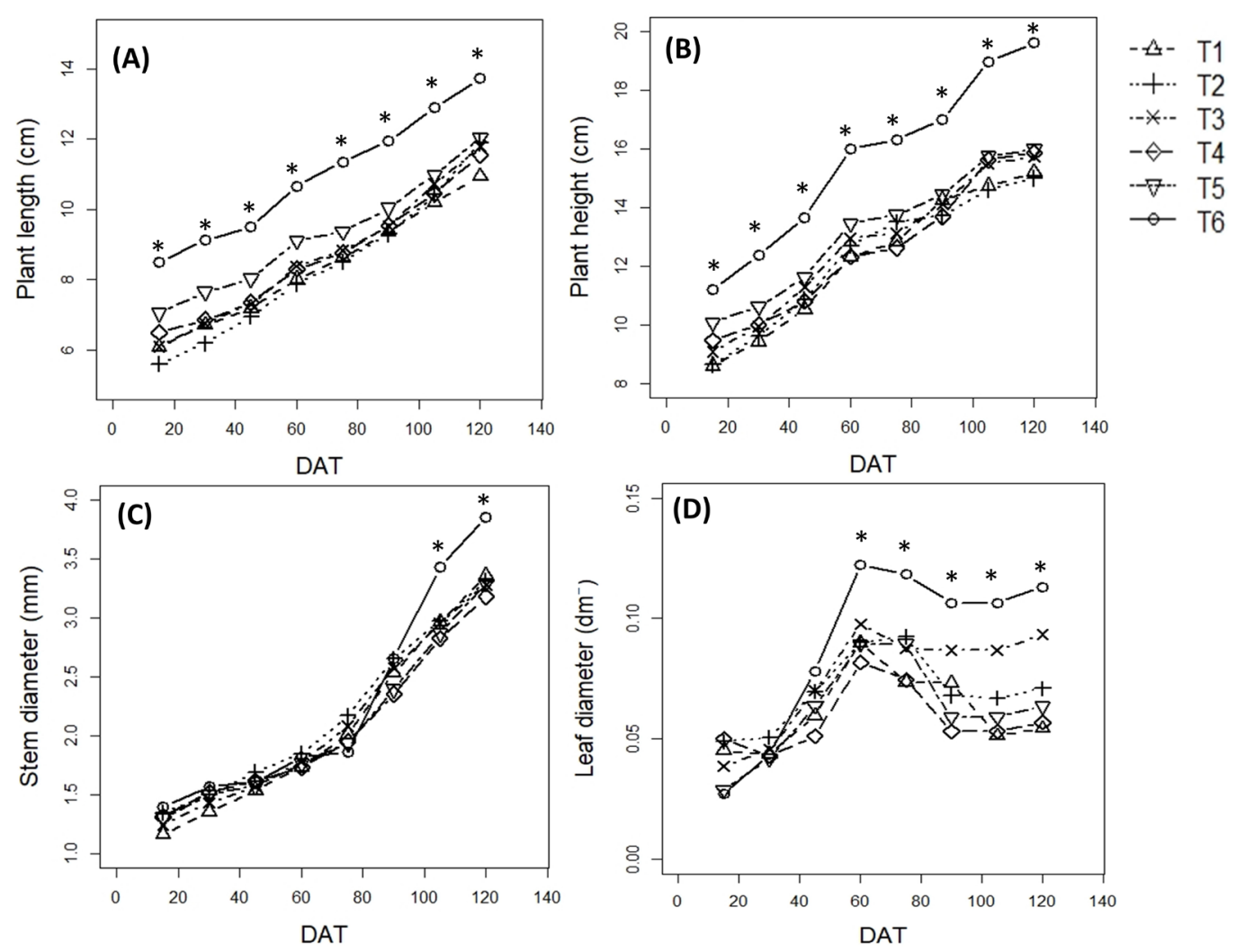

Figure 1. Growth analysis in young Passiflora edulis Sims. f. flavicarpa Degener plants (passion fruit) measures over time (days after transplanting - DAT) for different $\mathrm{N}$ ionic strength and foliar Mo and Co application conditions (T1, T2, and T3 are the 25, 50 and 100\% IS without spray; and T4, T5, and T6 are 25, 50 and 100\% IS with spray). Mean values from $\mathrm{N}=17$ replicates within each time. Evaluations in which there was group formation of means by the Scott-Knott method $(\mathrm{P}<0.05)$ are identified by asterisks $(*)$.

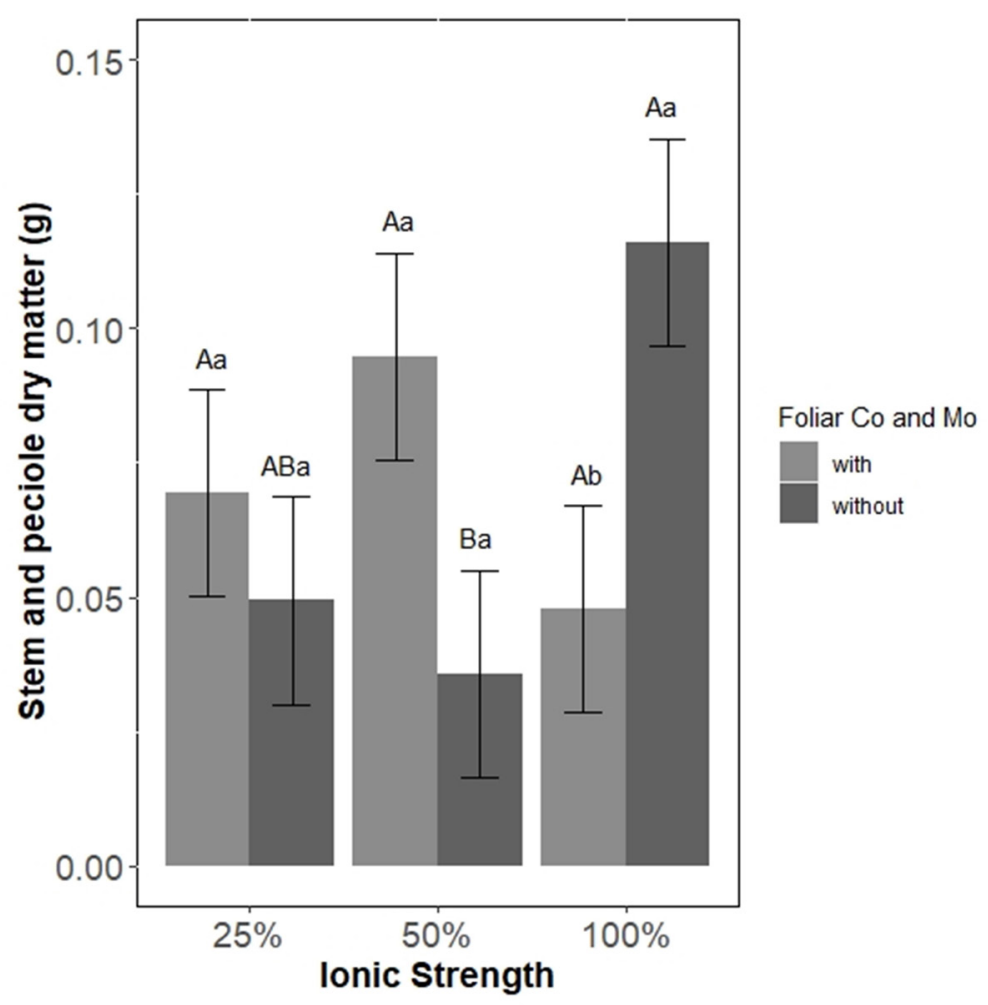

Figure 2. Stem and petiole dry matter of young Passiflora edulis Sims. f. flavicarpa Degener (passion fruit) plants as a function of foliar application and $\mathrm{N}$ ionic strength (Mean \pm Standard Error). Distinct letters indicate means statistically different by the Tukey's test with $\alpha=0.05$. Uppercase letters are used to compare ionic strengths for different foliar application conditions, while lowercase letters compare foliar application levels within each ionic strength. 
$0.5 \quad 1.0 \quad 1.5$
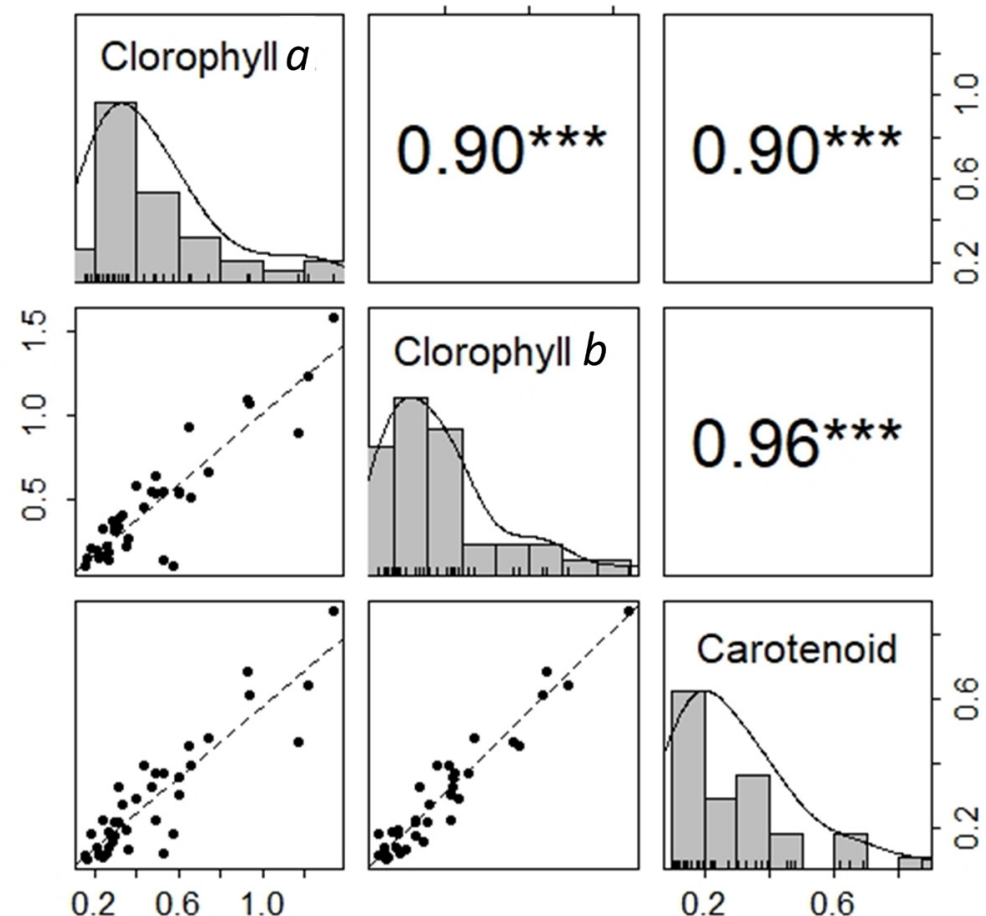

Figure 3. Distribution for chlorophyll $a$, chlorophyll $b$, and carotenoid pigment contents $(\mathrm{mg} / \mathrm{g})$ in Passiflora edulis Sims. f. flavicarpa Degener fruits (passion fruits). ${ }^{* * *}$ Pearson linear correlations were significant at level of alpha $=0.01$
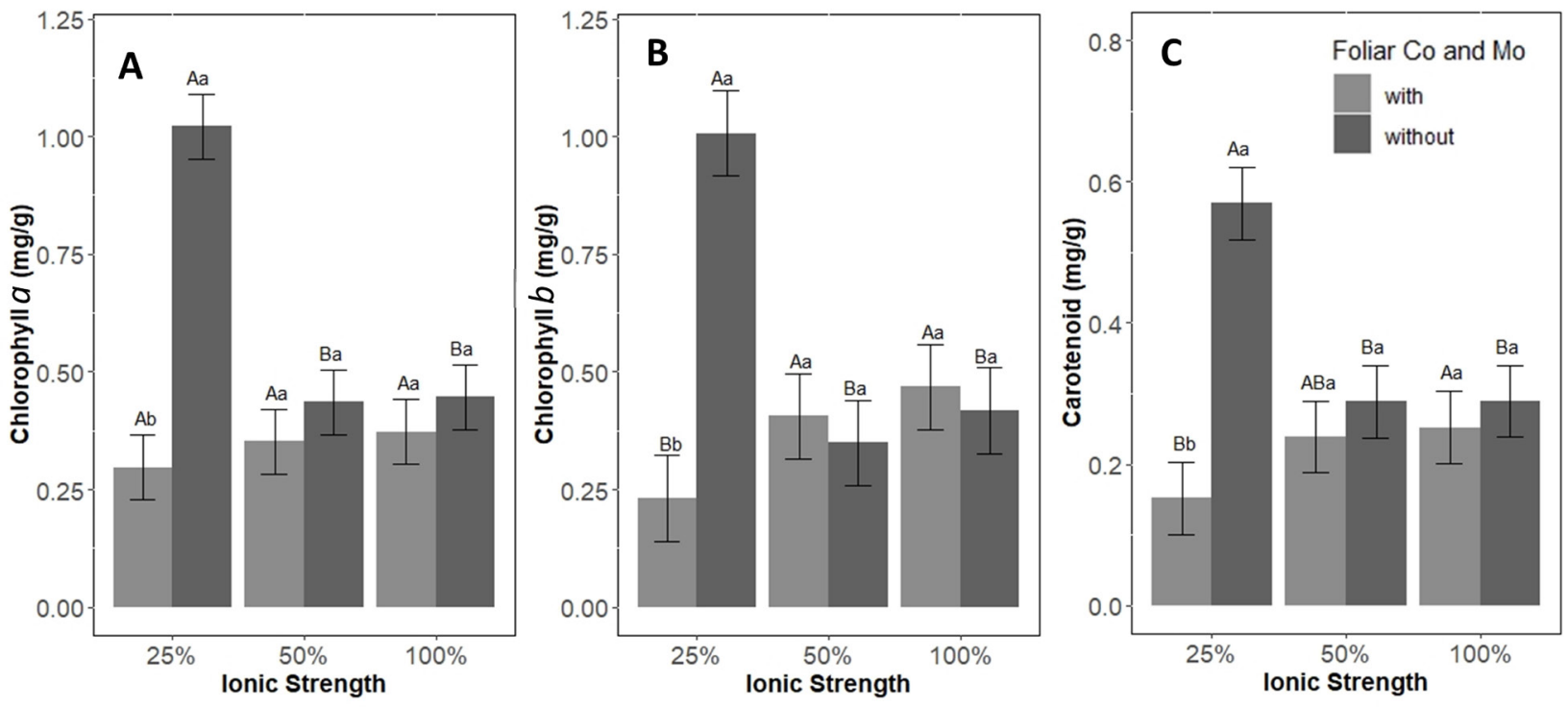

Figure 4. Contents of chlorophyll $a$, chlorophyll $b$, and carotenoid pigments of young Passiflora edulis Sims. f. flavicarpa Degener plants (passion fruits) for different N supply and Mo and Co foliar application conditions (Mean \pm Standard Error, $\mathrm{n}=6$ replicates). Distinct letters indicate means statistically different by Tukey's test with $\alpha=0.05$. Uppercase letters are used to compare ionic strengths for different foliar application conditions, while lowercase letters compare foliar application levels within each ionic strength. 
Remarkably, higher $\mathrm{NH}_{4}^{+}$concentrations cause reduction in dry matter mass production, as the plant will not be able to promptly incorporate all $\mathrm{N}-\mathrm{NH}_{4}{ }^{+}$carbon skeleton (absence of carbon skeleton), and with alkaline $\mathrm{pH}$, it would convert into $\mathrm{NH}_{3}$, which would cause cell phytotoxicity. Higher $\mathrm{NH}_{4}^{+}$concentrations were reported in root tissue in comparison with $\mathrm{NO}_{3}{ }^{-}$treatment, whereas plants maintained a concentration equilibrated of $\mathrm{NH}_{4}^{+}$ and $\mathrm{NO}_{3}{ }^{-}$in leaf tissue (RUAN; WEI; WANG; CHENG et al., 2016).

The use of the soilless cultivation technique is an excellent tool to assist in the manipulation of nutrient availability used in the roots of crops supplied via roots and to determine the nitrogen use efficiency (FAGERIA; BALIGAR, 2008). Nitrogen use efficiency (NUE) of eudicot angiosperms decreased at the early stage but increased later, on the other hand, for monocots, it decreased throughout the phenological growth stage (HAILE; NIGUSSIE; AYANA, 2012). Species that differed in $\mathrm{N}$ use shows different plant plasticity towards $\mathrm{N}$ source during the phenological growth stage. Legumes preferred $\mathrm{NO}_{3}^{-}$throughout their growth while grasses preferred $\mathrm{NH}_{4}^{+}$at the early stages but later switched the preference for $\mathrm{NO}_{3}^{-}$(CUI; YU; QIAO; XU et al., 2017) and higher plasticity may favor this species to mitigate $\mathrm{N}$ starvation stress. Inadequate $\mathrm{N}$ availability (i.e., unique $\mathrm{N}$ source) shows a morphophysiological change, assimilates partitioning and increases the root dry matter ratio (ZHU; CHEN; CHAN; YANG et al., 2018). However, in the present study, the experimental group treated with Co/Mo spray showed higher growth measurements cultivated in higher EC (100\%IS), while Co/Mo spray showed no relevant effects under low EC (25\%IS). Tomato (Lycopersicon esculentum L.) and tobacco (Nicotiana tabacum L.) are among the investigated species that have impaired vegetative development by adopting a single $\mathrm{N}$ source (RAHAYU; WALCH-LIU; NEUMANN; RÖMHELD et al., 2005; WILLMANN; THOMFOHRDE; HAENSCH; NEHLS, 2014).

$\mathrm{N}$ absorption and assimilation by plants are multiregulated processes and integrated with the general plant metabolism. The multi-regulation of $\mathrm{N}$ metabolism impairs the identification of specific metabolic points that are more limiting for increasing productivity. In addition to differential nutrient uptake, the use of $\mathrm{N}$ may also vary as a function of the $\mathrm{NO}_{3}{ }^{-}$and $\mathrm{NH}_{4}^{+}$ proportion in the root surface, as $\mathrm{NO}_{3}^{-}$to be assimilated needs to be reduced in a process mediated by nitrate reductase enzymes (EC 1.6.6.1) and nitrite reductase (EC 1.7.7.1), while $\mathrm{NH}_{4}^{+}$does not require this step to be assimilated into amino acids (BOSCHIERO; MARIANO; AZEVEDO; OCHEUZE TRIVELIN, 2019; WANG; MIAO; LI, 2015). $\mathrm{NH}_{4}^{+}$deprivation stress in tomato plants
(Solanum lycopersicum L.) is responsible for rapid leaf growth inhibition associated with decline in cytokine concentration in xylem exudate and younger leaf tissue. According to Glanz-Idan and collaborators (GLANZIDAN; TARKOWSKI; TUREČKOVÁ; WOLF, 2020), $\mathrm{NO}_{3}{ }^{-}$is a direct player to stimulate cytokinin accumulation in shoots, with leaf growth regulation. Thus, $\mathrm{N}$ starvation or its low availability leads to leaf growth inhibition due to the decline of CK concentration (RAHAYU; WALCHLIU; NEUMANN; RÖMHELD et al., 2005).

Regarding pigment contents, increased exposure of Co to leaves may cause damage to cell structural membranes (plasmalemma), such as inhibition of photosynthetic pigment synthesis. Co crosses the plant cuticle of air organs and after penetration is transported to other plant structures through the phloem in the same way as photosynthesis (SHAHID; DUMAT; KHALID; SCHRECK et al., 2017). The availability of Co in amounts from $100 \mu \mathrm{M}$ causes toxic effects such as reduced cell division, discoloration, and leaf abscission (LANGE; FAUCON; DELHAYE; HAMITI et al., 2017). In addition, leaf abscission in treatments deprived of ammonium $\left(\mathrm{NH}_{4}^{+}\right)$ source is a natural consequence of plant growth stress using a single $\left(\mathrm{NO}_{3}^{-}\right)$nutritional $\mathrm{N}$ source (CAMPOS; VIEIRA; AMARO; DELACRUZ-CHACÓN et al., 2019). Certain abiotic stress conditions (environmental and/or nutritional), such as $\mathrm{N}$ starvation, may alter the phytohormonal balance and osmoregulation in the plant cell. Conversely, in $\mathrm{NO}_{3}{ }^{-}$-fed plants, phenological growth stages may be delayed due to excessive concentrations of the plant cytokinin hormone $(\mathrm{CK})$, since $\mathrm{NO}_{3}^{-}$ion enhances active forms of this phytohormone (GARNICA; HOUDUSSE; ZAMARREÑO; GARCIA-MINA, 2010). With $\mathrm{NH}_{4}^{+}$deprivation in the root medium, plants develop a two-phase response.

In the first phase, the leaf elongation rate is reduced without affecting photosynthesis (ANANDACOOMARASWAMY; DE COSTA; TENNAKOON; VAN DER WERF, 2002). Root growth is maintained or even stimulated by the transport of assimilated carbon to roots, which results in lower shoot/root biomass ratio. Concomitantly, $\mathrm{N}$ compounds, particularly $\mathrm{NO}_{3}^{-}$, are mobilized to maintain $\mathrm{N}$ metabolism and the capacity to absorb $\mathrm{NO}_{3}^{-}$from the soil is increased. In the second phase, upon continued $\mathrm{N}$ starvation, the breakdown of leaf nucleic acids and proteins is triggered and, usually, associated with leaf senescence (HÖRTENSTEINER; FELLER, 2002). 
However, the present study reported that plants treated with Co/Mo spray at $100 \%$ IS ensured the permanence of leaves compared to plants without $\mathrm{Co} / \mathrm{Mo}$ treatment Co element play an important role in delaying leaf senescence by preventing chlorophyll degradation via blockage of the conversion of 1-aminocyclopropane1-carboxylic acid (ACC), by ACC oxidase, into plant hormone ethylene (Et) (DIVTE; YADAV; JAIN; PAUL et al., 2019). In addition, the understanding of this physiological inhibition mechanism is not yet elucidated, but it is known that Co forms a stable compound with the sulfhydryl group of this enzyme, blocking this action. According to Hänsch and Mendel (HÄNSCH; MENDEL, 2009), the aldehyde oxidase is a molybdoflavoenzyme derived from the duplication of the xanthine dehydrogenase gene and both use the same prosthetic groups (FAD ${ }^{+}, \mathrm{Fe}-\mathrm{S}$, and Mo-cofactor). This biochemical mechanism is crucial to obtain the biological function necessary to plant growth (MENDEL; KRUSE, 2012). In this way, we can speculate that the presence of Mo spray combined with nutrient solution composed of a single nitrogen (nitrate) source (absence of ammonium) promotes enzymatic catalysis of plant hormone auxin (AX) and benefits plant establishment during early phenological growth stages.

\section{Conclusion}

We concluded that the application of foliar Co and Mo spray combined with nutrient solution composed of a single nitrate source (absence of ammonium) did not affect dry matter accumulation, but the $\mathrm{Co} / \mathrm{Mo}$ treatment alleviate $\mathrm{NO}_{3}{ }^{-}$starvation $/ \mathrm{NH}_{4}{ }^{+}$deprivation stress during the initial phenological growth stages of Passiflora edulis Sims. f. flavicarpa Degener.

\section{References}

ANANDACOOMARASWAMY, A.; DE COSTA, W.A.J.M.; TENNAKOON, P.L.K.; VAN DER WERF, A. The physiological basis of increased biomass partitioning to roots upon nitrogen deprivation in young clonal tea (Camellia sinensis (L.) O.Kuntz). Plant and Soil, Dordrecht, v.238, n.1, p.1-9, 2002.

BENINCASA, M.M.P. Análise de crescimento de plantas: noções basicas. Jaboticabal: FUNEP, 1986. $41 \mathrm{p}$.
BOSCHIERO, B.N.; MARIANO, E.; AZEVEDO, R.A.; OCHEUZE TRIVELIN, P.C. Influence of nitrate ammonium ratio on the growth, nutrition, and metabolism of sugarcane. Plant Physiology and Biochemistry, Paris, v.139, p.246-255, 2019.

CAMPOS, F.G.; VIEIRA, M.A.R.; AMARO, A.C.E.; DELACRUZ-CHACÓN, I.; MARQUES, M.O.M.; FERREIRA, G.; BOARO, C.S.F. Nitrogen in the defense system of Annona emarginata (Schltdl.) H.Rainer. PloS One, San Francisco, v.14, n.6, p.e0217930-e0217930, 2019.

CHATTERJEE, R.; BANDYOPADHYAY, S. Effect of boron, molybdenum and biofertilizers on growth and yield of cowpea (Vigna unguiculata L. Walp.) in acid soil of eastern Himalayan region. Journal of the Saudi Society of Agricultural Sciences, Amsterdam, v. 16, n.4, p.332-336, 2017.

CUI, J.; YU, C.; QIAO, N.; XU, X.; TIAN, Y.; OUYANG, $\mathrm{H}$. Plant preference for $\mathrm{NH}^{4+}$ versus $\mathrm{NO}^{3-}$ at different growth stages in an alpine agroecosystem. Field Crops Research, Amsterdam, v.201, p.192-199, 2017.

DIVTE, P.; YADAV, P.; JAIN, P.K.; PAUL, S. Ethylene regulation of root growth and phytosiderophore biosynthesis determines iron deficiency tolerance in wheat (Triticum spp). Environmental and Experimental Botany, Amsterdam, v.162, p.1-13, 2019.

ESTRADA, N.L.; BÖHLKE, J.K.; STURCHIO, N.C.; GU, B. Stable isotopic composition of perchlorate and nitrate accumulated in plants: hydroponic experiments and field data. Science of the Total Environment, Amsterdam, v.595, p.556-566, 2017.

FAGERIA, N.K.; BALIGAR, V.C. Ameliorating soil acidity of tropical oxisols by liming for sustainable crop production. Advances in Agronomy, Amsterdam, v.99, p.345-399, 2008.

GARNICA, M.; HOUDUSSE, F.; ZAMARREÑO, A.M.; GARCIA-MINA, J.M. The signal effect of nitrate supply enhances active forms of cytokinins and indole acetic content and reduces abscisic acid in wheat plants grown with ammonium. Journal of Plant Physiology, Stuttgart, v.167, n.15, p.1264-1272, 2010. 
GLANZ-IDAN, N.; TARKOWSKI, P.; TUREČKOVÁ, V.; WOLF, S. Root-shoot communication in tomato plants: cytokinin as a signal molecule modulating leaf photosynthetic activity. Journal of Experimental Botany, Oxford, v.71, n.1, p.247-257, 2020.

HAILE, D.; NIGUSSIE, D.; AYANA, A. Nitrogen use efficiency of bread wheat: effects of nitrogen rate and time of application. Journal of Soil Science and Plant Nutrition, Cham, v.12, p.389-410, 2012.

HÄNSCH, R.; MENDEL, R.R. Physiological functions of mineral micronutrients $(\mathrm{Cu}, \mathrm{Zn}, \mathrm{Mn}, \mathrm{Fe}, \mathrm{Ni}, \mathrm{Mo}, \mathrm{B}$, $\mathrm{Cl})$. Current Opinion in Plant Biology, Oxford, v.12, n.3, p.259-266, 2009.

HAWKESFORD, M.; HORST, W.; KICHEY, T.; LAMBERS, H. Functions of macronutrients. In: MARSCHNER, P. (ed.). Marschner's mineral nutrition of higher plants. 3.ed. San Diego: Academic Press, 2012. p.135-189.

HIPPLER, F.W.R.; BOARETTO, R.M.; DOVIS, V.L.; GOMES, G.O.F. Revisiting nutrient management for Citrus production: to what extent does molybdenum affect nitrogen assimilation of trees? Scientia Horticulturae, Wageningen, v.225, p.462-470, 2017.

HOAGLAND, D.R.; ARNON, D.I. The water-culture method for growing plants without soil. California Agricultural Experiment Station, Berkeley, v.347, p. 32, 1950.

HÖRTENSTEINER, S.; FELLER, U. Nitrogen metabolism and remobilization during senescence. Journal of Experimental Botany, Oxford, v.53, n.370, p.927-937, 2002.

HUANG, L.; LI, M.; ZHOU, K.; SUN, T. Uptake and metabolism of ammonium and nitrate in response to drought stress in Malus prunifolia. Plant Physiology and Biochemistry, Paris, v.127, p.185-193, 2018.

LANGE, B.; FAUCON, M.-P.; DELHAYE, G.; HAMITI, N. Functional traits of a facultative metallophyte from tropical Africa: population variation and plasticity in response to cobalt. Environmental and Experimental Botany, Amsterdam, v.136, p.1-8, 2017.
LIU, M.-Y.; BURGOS, A.; ZHANG, Q.; TANG, D.; SHI, Y.; MA, L.; YI. X.; RUAN, J. Analyses of transcriptome profiles and selected metabolites unravel the metabolic response to $\mathrm{NH}_{4+}$ and $\mathrm{NO}_{3-}$ as signaling molecules in tea plant (Camellia sinensis L.). Scientia Horticulturae, Wageningen, v.218, p.293-303, 2017.

MENDEL, R.R.; KRUSE, T. Cell biology of molybdenum in plants and humans. Biochimica et Biophysica Acta (BBA) - Molecular Cell Research, Amsterdam, v.1823, n.9, p.1568-1579, 2012.

OLUOCH, P.; NYABOGA, E.N.; BARGUL, J.L. Analysis of genetic diversity of passion fruit (Passiflora edulis Sims) genotypes grown in Kenya by sequence-related amplified polymorphism (SRAP) markers. Annals of Agrarian Science, Tbilisi, v.16, n.4, p.367-375, 2018.

RAHAYU, Y.S.; WALCH-LIU, P.; NEUMANN, G.; RÖMHELD, V. Root-derived cytokinins as long-distance signals for $\mathrm{NO}^{3-}$-induced stimulation of leaf growth. Journal of Experimental Botany, Oxford, v.56, n.414, p.1143-1152, 2005.

RUAN, L.; WEI, K.; WANG, L.; CHENG, H. Characteristics of $\mathrm{NH}^{4+}$ and $\mathrm{NO}^{3-}$ fluxes in tea (Camellia sinensis) roots measured by scanning ion-selective electrode technique. Scientific Reports, London, v.6, p.38370-38370, 2016.

SHAHID, M.; DUMAT, C.; KHALID, S.; SCHRECK, E. Foliar heavy metal uptake, toxicity and detoxification in plants: A comparison of foliar and root metal uptake. Journal of Hazardous Materials, Amsterdam, v.325, p.36-58, 2017.

SIMS, D.A.; GAMON, J.A. Relationships between leaf pigment content and spectral reflectance across a wide range of species, leaf structures and developmental stages. Remote Sensing of Environment, New York, v.81, n.2, p.337-354, 2002.

TANG, D.; LIU, M.-Y.; ZHANG, Q.; MA, L. Preferential assimilation of $\mathrm{NH} 4+$ over $\mathrm{NO}^{-}$- in tea plant associated with genes involved in nitrogen transportation, utilization and catechins biosynthesis. Plant Science, New York, v.291, p.110369, 2020. 
WANG, Z.H.; MIAO, Y.F.; LI, S.X. Effect of ammonium and nitrate nitrogen fertilizers on wheat yield in relation to accumulated nitrate at different depths of soil in drylands of China. Field Crops Research, Amsterdam, v.183, p.211-224, 2015.

WILLMANN, A.; THOMFOHRDE, S.; HAENSCH, R.; NEHLS, U. The poplar NRT2 gene family of high affinity nitrate importers: Impact of nitrogen nutrition and ectomycorrhiza formation. Environmental and Experimental Botany, Amsterdam, v.108, p.79-88, 2014.

WILSON, S.B.; NICHOLAS, D.J.D. A cobalt requirement for non-nodulated legumes and for wheat. Phytochemistry, New York, v.6, n.8, p.1057-1066, 1967.
YIN, X.-M.; LUO, W.; WANG, S.-W.; SHEN, Q.-R. Effect of nitrogen starvation on the responses of two rice cultivars to nitrate uptake and utilization. Pedosphere, Amsterdam, v.24, n.5, p.690-698, 2014.

ZENG, W.-Z.; XU, C.; WU, J.-W.; HUANG, J.-S. Impacts of Salinity and Nitrogen on the Photosynthetic Rate and Growth of Sunflowers (Helianthus annuus L.). Pedosphere, Amsterdam, v.24, n.5, p.635-644, 2014.

ZHU, F.-Y.; CHEN, M.-X.; CHAN, W.-L.; YANG, F. SWATH-MS quantitative proteomic investigation of nitrogen starvation in Arabidopsis reveals new aspects of plant nitrogen stress responses. Journal of Proteomics, Amsterdam, v.187, p.161-170, 2018. 